


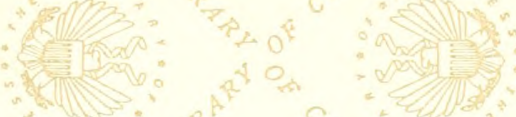

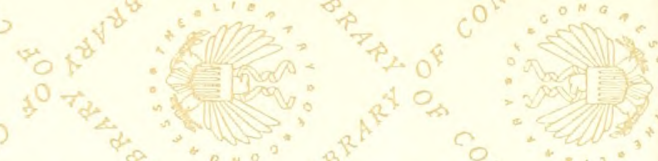

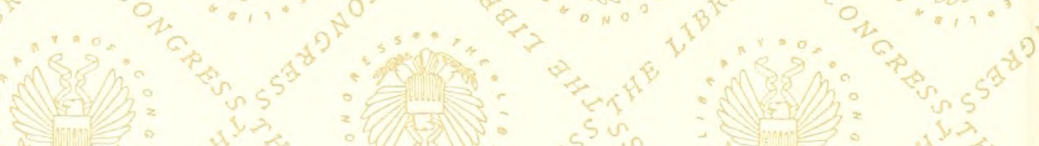
5 a
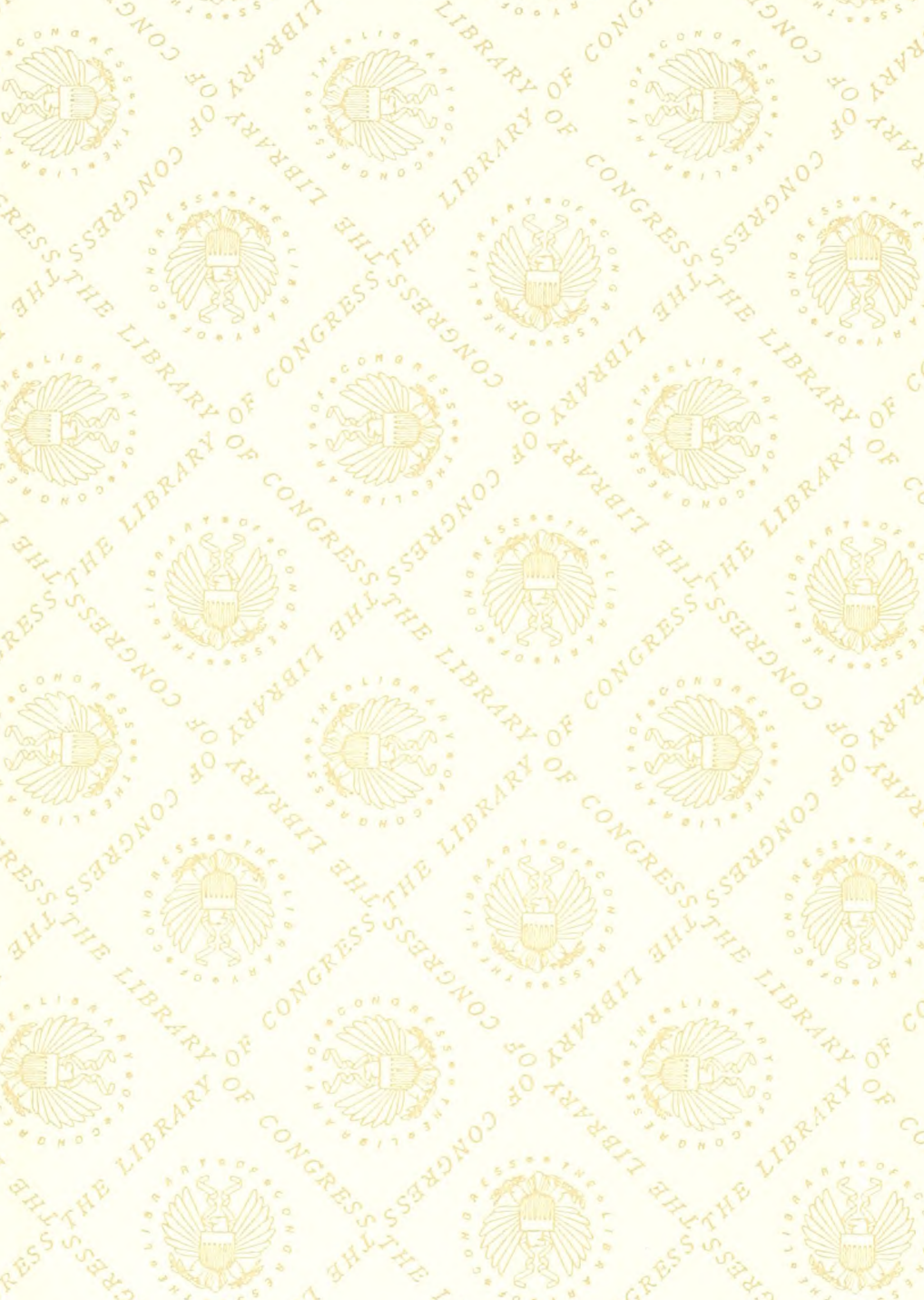

and
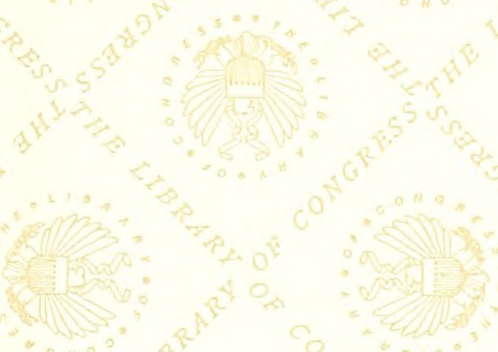

(2)
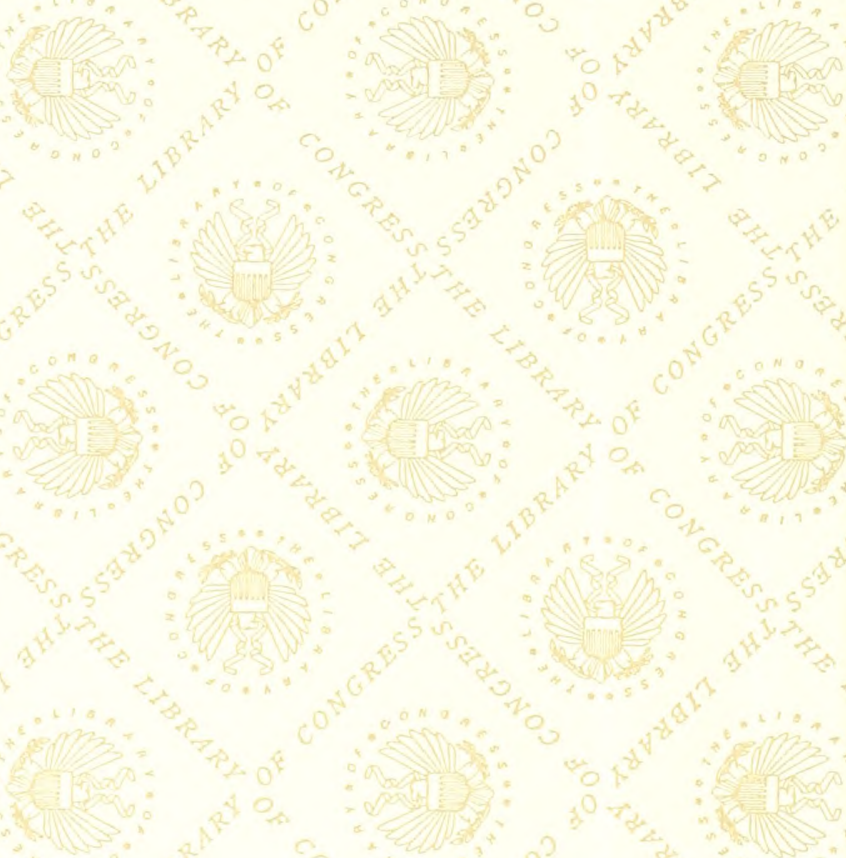

a
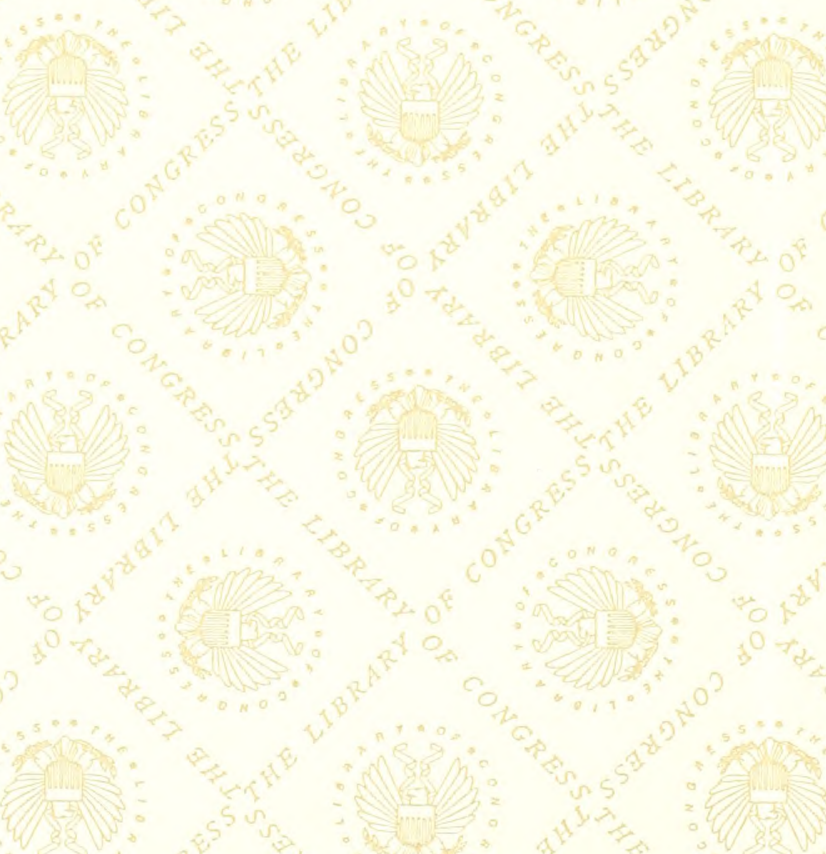


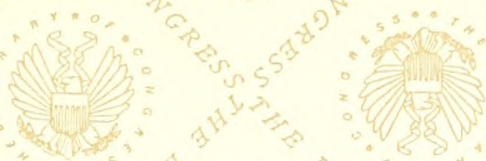

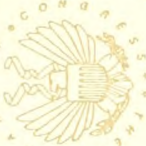

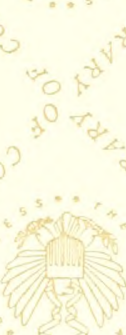

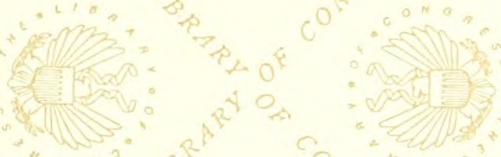
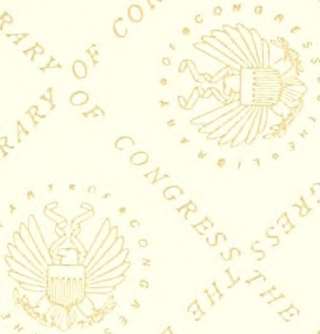

$5^{5^{2 x^{2}}}=\frac{5^{5} \cdots}{20}$

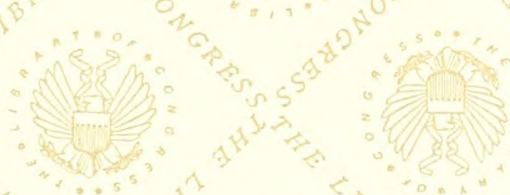

" ondin'

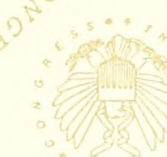

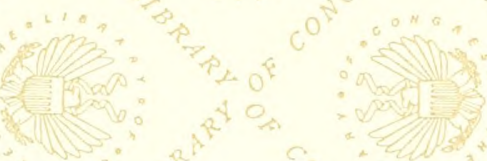
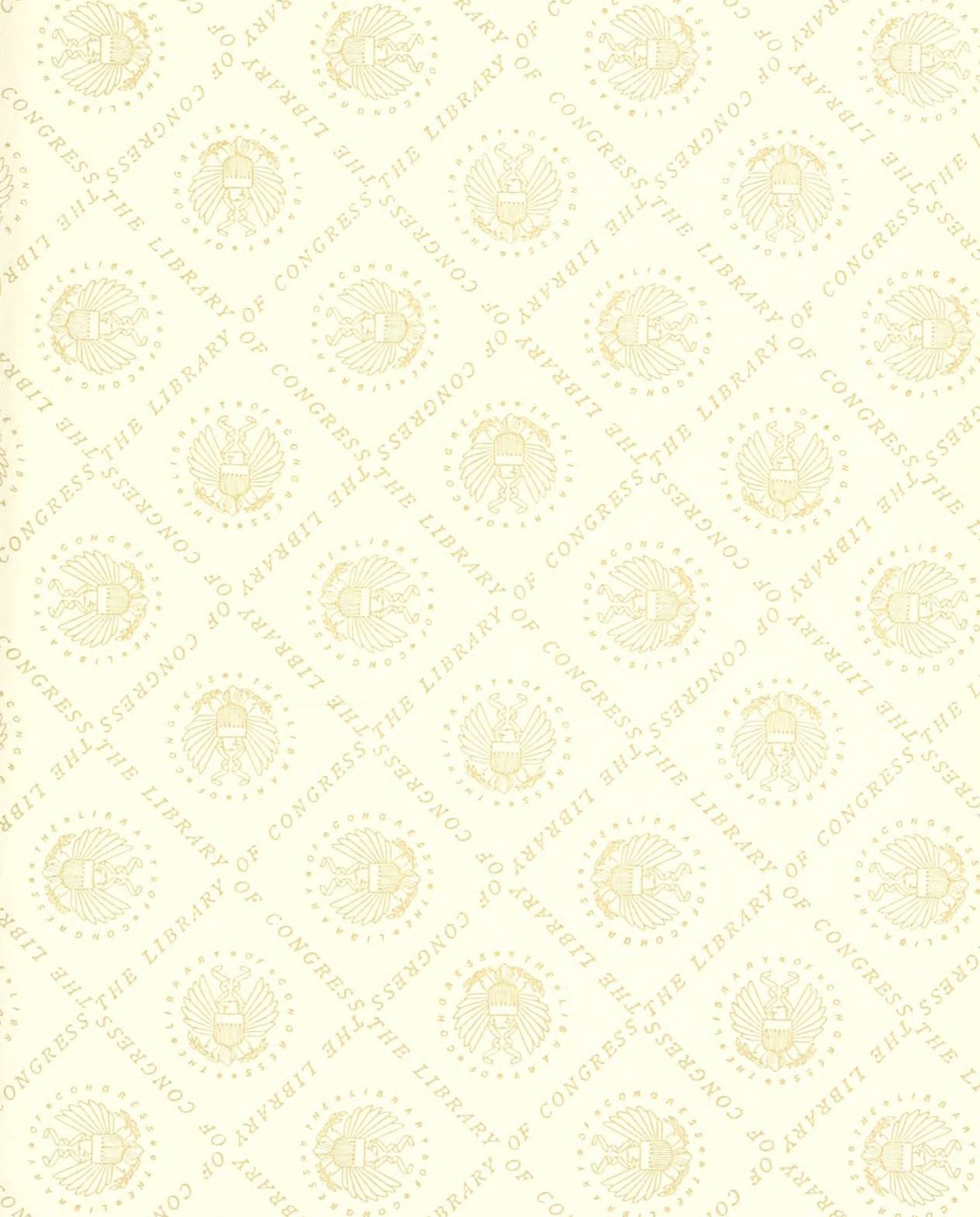






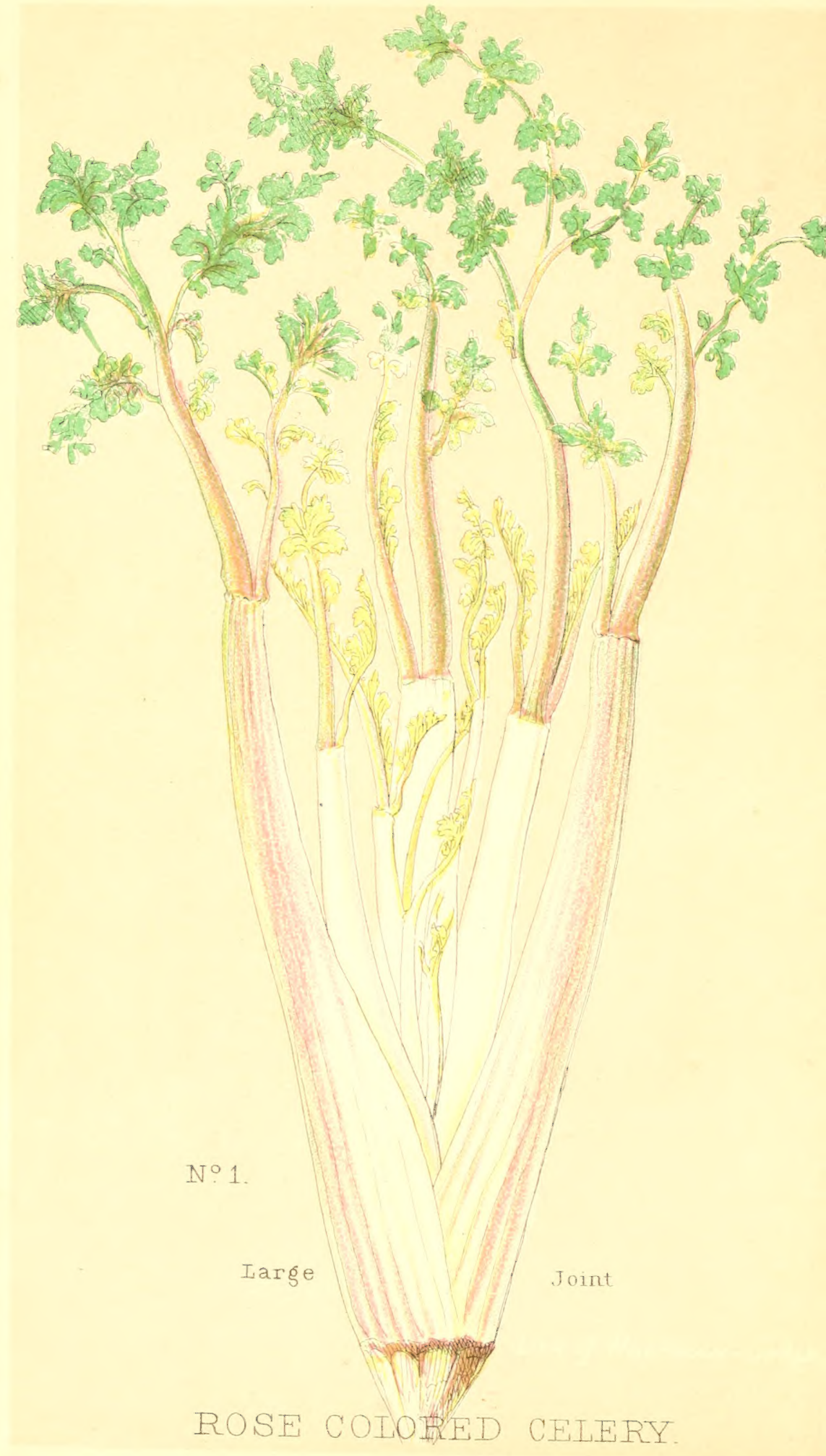




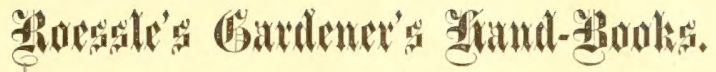

$$
\text { No. } 1 \text {. }
$$

\section{HOW TO CULTIVATE AND PRESERVE}

\section{E L E R Y.}

BY THEOPHILUS POESSLE,

of the delavan house, albant, $N, \quad$.

EDITED, WITH A PREFACE,

BY HENRY S. OLCOTT.

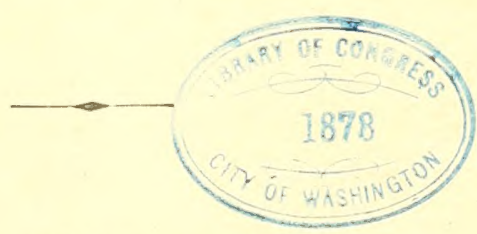

ALBANY :

THEOPHILUS ROESSLE, DELAVAN HOUSE.

NEW YORK : C. M. SAXTON, BARKER \& COMPANY. AND BY ALL BOOKSELLERS. 1860. 
Entered according to act of Congress, in the year 1860, BY THEOPHILUS ROESSLE, in the Clerk's Office of the District Court of the United States for the Northern District of New York.

MUNSELL \& ROWLAND, PRINTERS, ALBANY. 


\section{CONTENTS.}

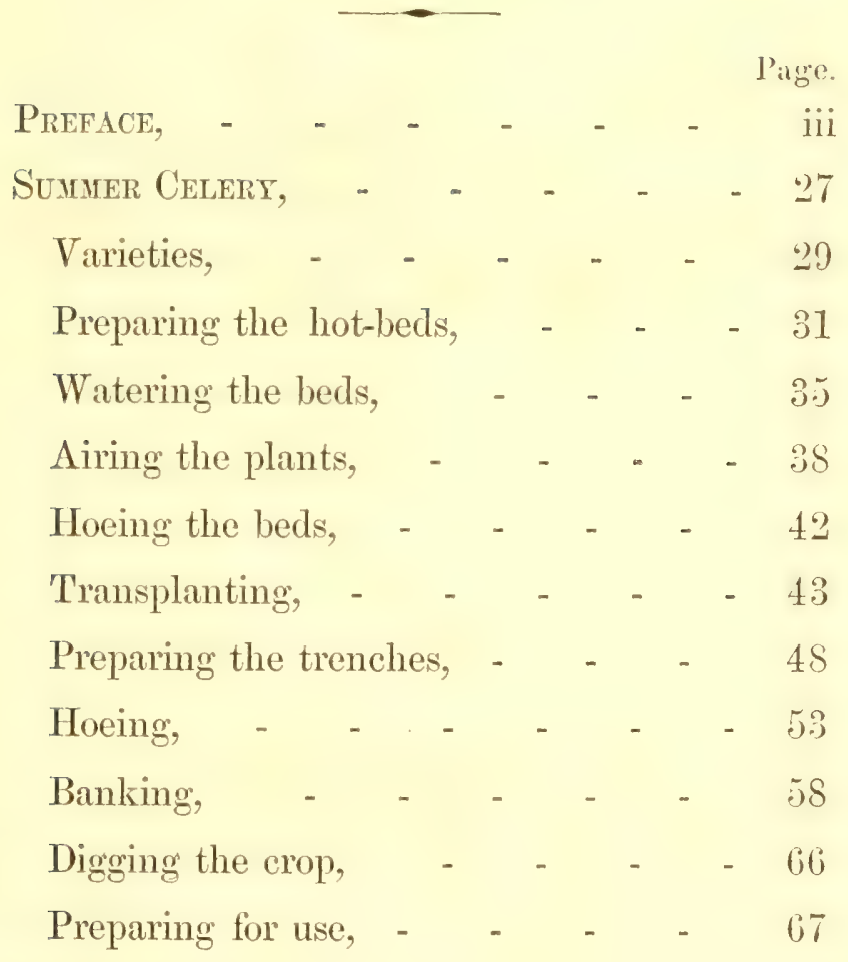


CON'IENT'S.

Page.

Winter Celert, - $\quad$ - $\quad$ - $\quad$ - 71

Preparing the ground, - $\quad$ - 7 .

Sowing and hoeing, - _ _ $\quad$ - 76

How and when to bury, - $\quad$ - $\quad$ -

Covering for the winter, _ _ $\quad$ - S.)

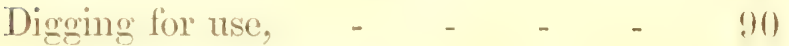

Otiler Haxd-Books, - $\quad$ - $\quad$ -

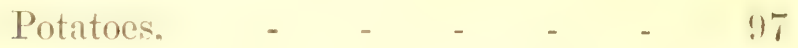

Coln, - - $\quad$ - $\quad$ - $\quad$ - $\quad$ -

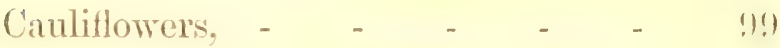

Cabbage, - $\quad$ - $\quad$ - $\quad$ - $\quad$ - $\quad$ -

'T'umips, 


\title{
ILLUSTRATIONS.
}

\author{
Page. \\ Rose-Colored Celery, - - - - Front. \\ White Celery, - $\quad$ - $\quad$ - $\quad$ - $\quad$ - 27

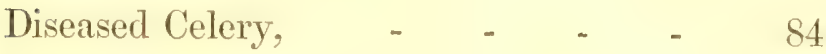 \\ Illustrations of Treatment, - _ _ 70 \\ Fig. 1, Celery in Trenches. \\ 2, Size at First Hoeing: \\ 3, First Banking. \\ 4, Slope of Hill. \\ 5, Buried for Winter. \\ 6, Second Banking.
}





\section{PREFACE.}





\section{PREFACE.}

In every business, trade and profession, we see some men, who, with no better chances than their neighbors, somehow thrive and grow rich; while others fail. The unfortunate ones, unconscious of the real causes of their disappointment, think themselves the victims of malign influences, and bewail their bad luck. The sober sense of the world, however, judging impartially in the case, decides that the successful man has conquered his fortune by being industrious, economical, observing; by a straight forward and persistent 
policy, and by using foresight and good judgment.

True as this is in all oceupations, there is none, perhaps, to which the rule will apply with more certainty than that of market-gardening. Almost every regetable which we use has been produced, by skill and care, from an inferior, wildgrowing plant, and there is a constant tendency to revert or fall back to that original condition; a result which we prevent only by the diligent use of skillful treatment. Thus it is with the potato, the tomato, asparagus, rhubarb, celery; and when we come to fruits, we find the same rule applying to the apple, peach, plum, pear, and others. The regular processes of nature have been changed by man for his own purpose, and plants, trees, and 
even animals have been forced to develop to excess the parts most suitable for human food, at the expense of those the least valuable. Thus the apple and peach, which in their original wild state aimed only to produce their seed, have by art been made to surround that seed with a mass of pulp, which is made greater in quantity, and more luscious in flavor, according to the treatment we bestow upon the trees. Asparagus, in its natural state a sea-side grass, spindling in size and useless for food, has when transplanted into the garden and carefully cultivated been made to produce thick, tender, succulent stalks, and is now one of our most delicious vegetables. So with celery. In its wild state, in which it is found in ditches throughout Europe, it is rank, coarse, and 
vi

PREFACE.

even poisonous, but by cultivation it becomes clisp, sweet, juicy, and of an agrecalle flaror. Turning to the animal kingdom, we see our domestic cow, which otherwise would secrete only enough milk to suckle her young and, this accomplished, go dry the rest of the year, made by the art of man to yield for her owner ten, twenty, and sometimes cren more quats of milk raily. And in the matter of beef production, we see how the intelligent lahors of Colling, Bates, Quartly, Turner, and their compecrs, have resulted in the production of animals which convert their food almost entirely into the most valuable portions of meat.

Again, we must remember that many of our common vegetables are natives of tropical or very warm climates; in which 
they run through all the stages of growth unchecked by frost or cold, and are planted by nature in the very soils which are best adapted to produce their fruit in greatest luxuriance. From these favorable climes they have been brought to struggle with our changeful seasons, and are often planted on soils in every way unsuited to them. If, therefore, we expect them to not only do as well but much better than they did at home, it is but fair to suppose that we must give them extraordinary attention, and by our vigilance avert the ill effects of sudden alterations of temperature.

The intelligent reader will understand, from these illustrations, that if we would control the laws of nature to work for our profit we must exercise a diligence and skill 
and give an attention to minor details, more unremitting as the desired result is of importance to us, and in contravention to the ordinary course of Nature. The skillful gartener not only maintains but continually improres the quality of his regetables, and by a close study of the laws of their growth, is enabled to originate, or ereate, new and better varieties.

It needs but a cursory glance at the nature of celery to make us see why it has been so difficult a matter to raise it of the best (puality, and keep) it sound as long as we choose to send it to market. Sow the seed and leave it to itself and the plant will grow rank, with abundance of leaves, its stalks all green, excepet a little portion at the heart, and in due season it produces its seed abundantly. But we want its 
stalks to blanch and become crisp, and attain as great a length as possible. So we transplant it when a few inches high, and when the stalks have grown awhile we surround them with earth. The plant thus hemmed in, and having no access to the sunlight exeept at the top, pushes upward, as a man confined in a narrow tube would struggle upward to get free, and the juices not being acter upon by sunlight, the chlorophyll, or green coloring matter, is not claborated, and the stalks grow white. Does any one suppose that when a plant is thus surrounded with earth it is as little liable to disease, as when exposed to the air in its natural state? The stalk is composed of a fragile cellular structure which abounds with watery juice, in which, besides other in- 
gredients there is a small proportion of sugar in solution. So long as a certain temperature is maintained, with only a given density of soil, air and heat will be strpplied to the stallis in such proportion that the plant remains in health, and its growth is mimpeded. In this case the only change from a sate of Nature is that the green coloring matter is not elaborated, and the stalk grows white. But once pass this point and what is the result? shut out firm air and light, surlden with earthy water in which it is forced to grow, the stalk becomes unhealthy, its sugar changes to acid, the woody tissues are burned or rusted, decay and then decomposition ensues. In other words, there is a certain definite quantity of air and light required by a celery plant to 
preserve a state of health, the delicate tissues of its stalk mill withstand only a limited amount of maltreatment. and the exact processes of culture which we must pursue to secure a good crop of Celerry and keep it afterwards, can onls be learnt by long experience in the business.

We frequently see men engage in the busines of regetalile growing without the slightent intelligent irlea of the nature of plants, without patience and industrious habits, and with so little common sense as to expect large and good crops without manure or high culture. These, and their number is rery great, are the ones who fail, and bewail their luck, and grom poor and poorer, and finally sink to the condition of hired laborers for their more clever neighbors. These are the men who find 
their soils "not suited to cauliflower's," so little in fact, that out of every thousand plants they get a bare half dozen of marketable hearls. If they attempt a crop of onions, they somehow get nothing but scullions. Their turnips and radishes get pithy and worthless. Their cahloages will not head. 'Their beets, parsnips, and carrots, grow spindling roots, and they pour mpon the heads of their seedsmen every invective and malediction. It is in vain that they are told that the seed linem the same bag has poloduced splendid crops in a number of instances: ther know that the seedsman is lying, or at any rate that some extraordinarily farorable cireumstances must have attended the other cultivators. If they set out an orchand, their trees grow poorer than those of other 
men, and when they should rejoice in a crop, get nothing but faggot wood. The same "bad luck" enters their stables and styes, in the form of disease and accident to their occupants.

Such a man is not Mr. Theophilus Roessce, the author of this little pamphlet; as a sketch of his personal experience will abundantly show.

Born near Stuttgardt, in the Kingdom of Wirtemberg, and the son of a marketgardener and vigneron, he learnt the habits and cultivation of plants from his very boyhood. The plow, spade, hoe and pruning-knife were made familiar to him in turn, as he became large enough to be of service on the farm; and, like all the children in that kingdom, he got a good education. In 1825, he came to this 
xiv

PREFACE.

country a mere stripling. With another lad he found his way to Rochester, hut at Utica the baggage of hoth was lost, and they were left penniless in a land of strangers. The companion sickened and died in Rochester, and young Roessle, dispirited and aneworn, painfully trudged back on foot to Utica, in the bare hope of recovering his lost trunk. It was a bootless elrand, however, and so he turned his fice toward Allamy again. For many a weary day he walled in his worn shoes, without a change of raincnt to his back, or a penny in his pocket, a strange lad in a country where he could not make his commonest wants understood except by signs. He arrived at length, foot-sore and weary, at the last toll-gate on the Schenectady turnpilie, and when he was 
speculating on his chances for a breakfast, a farmer drove his team up to the tavern door, and beckoning the young lad to him got him to hold the horses while he went in to his breakfast. For this service he gave Roessle a sixpence, and that money was the corner-stone of a fortune.

Arrived in Albany, he met a little girl selling matches, and encuiring of her for her father, was led to a dirty room in a dirty street, where the girl's father, an old Swiss, the wife, and sereral children slept on straw. Roessle obtained the privilege of a night's lodging, and the next morning, finding that a few inches of snow had fallen through the night, he borrowed a shovel of the old man and went out to earn some money. He made a dollar and a half that day; and the next earned a like 
xvi

PREFACE.

sum loy sawing; splitting, and piling some fire-rood. He then got a job of sawing a dozen cords for an old Dutch Dominie, and while at this work the attention of old Dr. Peter Wendell being attracter to the diligence of the lad, a bargain was struck ly which Rocsisle was to have his board, two suits of clothes, and forty dollar's in cash per annum, in return for sweeping out the Doctor's oftice, and riding his rounds with him. He was thus employed nearly four yoars, but then went out to a firm on the Western Turmpike, which he leased for a term of year's from his employer. He now commenced his makket-gardening on a small scale, feeling his way and using his little capital to the best advantage. An English landscapegardener, named Scars, took board with 
him, and Roessle employed the opportunity afforded by the long winter evenings to learn as much of Sears's beautiful profession as he could. In spring he was employed to lay out the place of Mr. John Prentice, and the work was so well done that a number of luerative jobs were in succession offered to and executed by him. Joining the two trades together, working hard early and late, and living with the strictest frugality, Roessle accumulated property by slow degrees and bettered his circumstances. The quality of his vegetables became at last so well known, that his marketing business increased until he was forced to abandon landscape-gardening altogether.

Celery was his heaviest crop, for he not only retailed, and jobbed it out in Albany, 
but sold it at wholesale to other gardeners, and supplied Washington and Fulton marliets in New Tork, the River boats, Saratoga hotels, the Catskill Mountain House, and the city of Schencetady. From 18:3e to 1810 he sold an average of one thousand hunches a day. As he says himself, he conld laise perhaps as fine a crop of eclery then as he has been able to flumg the past few years, but as he could never succeed in keeping it over winter, he was no better off than his neighhors. It was only after failues, losses, and disappointments, that he discovered the simple expectients detailed in this little work; and he estimates that it has cost him between nine and ten thousand dollars to acquire the knowledge which the reater gets in the succeeding pages for an hundred cents. 
It is only within ten years that he has had partial, and within four years absolute, success in keeping celery sound and good throughout the winter and even as late as the month of May. A record of the successive failures which he has had, would doubtless cover the separate experiences of a score of celery growers; and if only a portion of them be given at this time, it is for the reason that it does not matter so much what he has gone through, as that he now succeeds, and can tell his reader's how to do likewise.

Mr. Roessle's gardening was first on seven acres, but as his sales increased he leased adjoining places, and got up successively to fifty, and finally one hundred and sixteen acres. For two acres of ground which he wished to use for celery 
growing, he paid an annual rent of fifty dollars per acre-and made moneyateven that price. He usually raised twenty-fire to thirty acres of potatoes, and sometimes fifty ; five of radishes, tive or six of peas, fifty to sixty thousand heads of celery, and all the ordinary vegetahles in various quantities. In 1836 he spent a winter at his home in Stuttgardt, and in so doing spent all his money, except a bare humdred dollars with which he got back to Albany. His credit was so good that he had no trouble to get what land he needed, and so he went to work again in good earnest. That year there was a severe drouth in Southern New York, and regetables were very scarce and very dear in market. Roessle, with characteristic shrewdness, bought up all the crops about him in 
advance, and from their sale and that of his own produce, realized a clear profit of $\$ 2,000$. This made him again a free man, and he has kept so ever since.

It has already been stated that his present knowledge has been obtained after many unfortunate failures. As a case in point, he mentions the fact that he once hired the cellars of three large grain warehouses, at a rent of about $\$ 200$, with a riew to storing his celery throughout winter. He carefully carried the plants a full mile from his farm to the cellars, carted in his dirt, and counted upon his prospective profits to meet certain heavy expenses. Alas for his calculation! the whole crop, which should have netted him over $\$ 2,000$, was a dead loss, and he had to cart his dirt "to the place whence it 
came;" thus not only losing his crop outright, but being forcerl to "throw good money after bad," in cleaning out the cellars, which had done all the damage.

Another time he built an outrloor cellar, or pit, and lomied in it $3,5,0(00)$ bunches, laying them down and orerlapping the tops; the whole mass rotter in less than three weeks. Again he put some 12,000 bunches into drills on the south side of a fence, covering each drill with a doublepitch roof of hoards; but to no avail, fol' his crop was not saved. And so by degrees he went on, learning one thing one season, another the next, and at last learning the whole secret of celery growing, as set forth in these pages. Last year Mr. Roessle had a crop so fine that a single head weighed six and a half 
pounds, the stalks four feet in length, three feet of which was white and to use the expression which I recently heard, "as clear as a lily." The quality seems to have been appreciated by the guests of the Delaran House, for twelve thousand heads have been eaten at its tables within the past ninety days. It is to be found on the table, I am told, from July until the following May, and of almost uniform quality throughout.

As will be seen in another place, $\mathrm{Mr}$. Roessle has yielded to repeated solicitations, and announces several pamphlets to follow the present one. It is intended to make a series, each pamphlet devoted to some special regetable, and to that alone, giving not so much chemical theories 
or useless speculations, as the plain unrarnished description of his own practical experience. To be sure he has his own theory as to the cause of potato-rot, and as to the action of manures, or the growth of plants; and while he may in stating his views rum comnter to the popular notions of the day, he hopes the public will not, in combating the shadows he throws, lose sight of the important substance contained in his experiments.

So far as the Editor is personally concerned, he wishes it understood that his office is to prepare the matter for the press, not to construct or correct the theories of the author: and he hopes to have the good taste to forluear from marring, by interlineations or foot-notes, the 
force of those peculiar views, even though they might in some instances widely differ from his own.

The personal experience of $\mathrm{Mr}$. Roessle has been sketched at some length for two reasons. First: He is a successful man, who first made enough money at marketgardening to warrant his leasing a large hotel, and since then has built up a fortune. Second: Because we have already had too many agricultural books written, and journals edited, by men of little or no practical experience, who are thus unsate preceptors for the confiding reader. When we know that this book on celery condenses into its score or two of pages the practical experience of twenty-five years, we are compelled to listen respectfully to the directions which it gives for our own 
practice; and when we give our own gardener order's to treat the celery after a given fashion at a given stage of growth, we are able to prophecy what results will follow, by turning over a few more leaves of our little manual and reading what its experienced author says.

'The other hand-hooks of this series will appear as rapidly as circumstances may permit.

H. S. 0.

New York, March, 1860. 



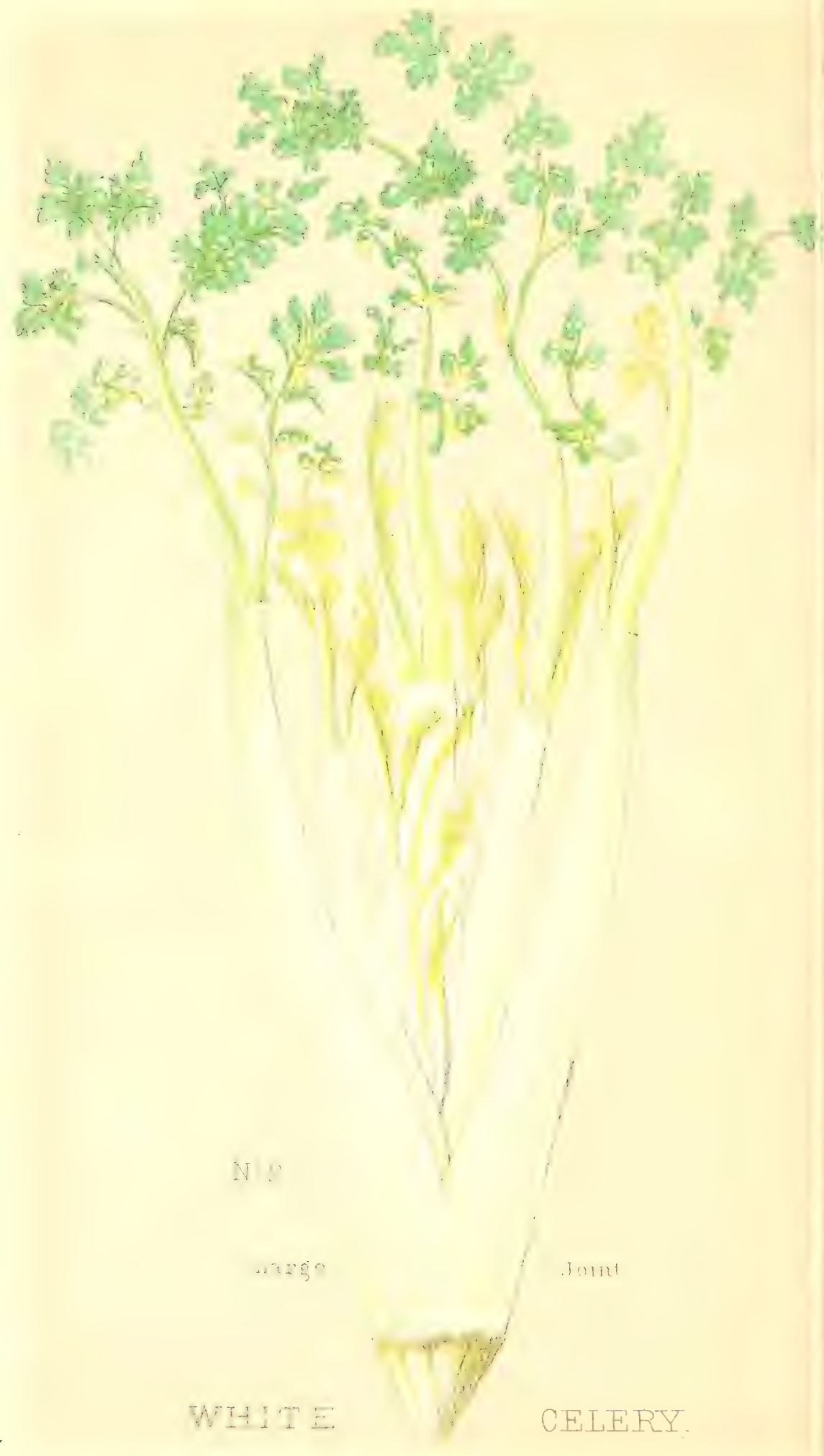


SUMMER CELERY. 



\section{S U M M E C E L E R Y.}

\section{VARIETIES.}

After an experience of many year's, with a great number of varieties of celery, I have narrowed my list to the following few kinds which I recommend as most profitable for general cultivation:

No. 1. Early White Solid.

No. 2. Joint do

No. 3. New Silver Leaf.

No. 4. Red Solid, or Rose-colored.

No. 5. Celeriac-or Turnip-rooted.

The varieties 1, 2, and 4 are best. I recommend number 1 for an early, and 
number 2 for the main crop. There are doubtless other kinds which under peculiar cireumstances ale valuable, but none I think which in every respect are so raluable, both to the market-eardener and the private cultivator, as those above mentioned. 
CELERY.

31

\section{PREPARING THE HOT-BEDS.}

The hot-beds should be made ready for the reception of the seed as early as the first day of March, in this latitude. I do not propose to enter into the details of their construction, further than to say that when finished with the manure, a depth of about twelve inches of fine soil should be added, the surface leveled, the sashes closed, and after being covered with straw mats, the bed should thus remain for ten days before a particle of seed is sown. The object of this plan is to raise a full crop of weeds, which at the expiration of the ten days may be all destroyed, and the soil be thus left clean for the crop of plants. Those 
who neglect this precaution suffer the penalty. 'Their tender', slow growing, young celery plants are choked with the more vigorous weeds: or the weeds are removed at the cost of great labor and expense.

The berl heing now thoroughly cleansed of weeds, it should he dug orer and raked, and a slope given to the surface corresponding to that of the glass above. 'To make drills for the seed, take a slat three inches wide and of the desired length, and press it edgewise into the soil to the depth of an inch; making the depth uniform throughout. Thus the seed being deposited at an eyual depth the plants will come up simultaneously, and be of one hight. The drills should be six inches ap)art. The old plan, it will be recollected, is to make the drills with a small marker, 
the drawing of which through the ground makes a bottom of unequal depth; and some seed having two inches, others only a half inch of soil over them, the appearance of the sprouts above ground is very various. By the plan which I recommend, the bottom of the drill is not only level but compact, and the moisture there retained, not only makes the seeds sprout sooner, but the plants more healthy. I need scarcely enlarge upon the importance of giving to plants of any kind a good healthy organism at their very start in life. For surely no intelligent man need be told that if the powers of our plant be enfeebled when they should be most vigorous the damage is irreparable. The delicate cellswhich should rapidly elaborate its food are imperfectly formed, and 
feeble, and the roots, few in number and dwarfed in size, are unable to atsorts from the soil food sufficient for a vigorous growth. It is as if we ruined the constitution of a child and expected him to develop into a healthy man. All the efforts, therefore, of the garlener should be directed to giving his plants a sound organism during the first stages of its growth.

By learing the hot-bed unsorn for ten days we gain an alvantage heyond the cradication of weeds, in such a settling of the bed that when the seed is sown the surface does not crack and hecome uneven. 
CELERY.

\section{WATERING THE BEDS.}

This should be done at noon, and only cold water should be used. As soon as one bed is watered close it up tight, and then proceed to another, and so on in succession. By thus doing the moisture in the bed will be evaporated by the sun's rays, and deposit on the glass in the form of a dew, thereby not only forming an agreeable shade to the plants, but giving to them by degrees a shower of dew-drops as they most need it. By this means I escape the great loss of having my plants "damp-off" at the root; a disaster which too often overtakes those who pursue the old method. It would be difficult, I fancy, 
to fairly estimate the number of celery plants thus lost every year, but it must be set down at many millions. Since using my plan I find inat my plants make as much growth in one day as I formerly could get in six, and the risk is almost nothing. Why the moisture thus condenses may be easily explained, and a single illustration will suffice to make my meaning plain. If we pour ice-water into a tumbler, in a room the temperature of which is 70 dex. Fahr.. beads of moisture will at once collect on the outside of the glass. This moisture has of course not oryed thromgh the glass, hut been forced to separate from the layers of atmosphere which touch the cold glass. It being a fact that the air can hold more water in a state of rapor as its own temperature 
CELERY.

is raised, and of course must lose it whenever that temperature is suddenly reduced. Thus there is much more water in the air at noon on a hot July day, than on one in November when we can scarcely see a dozen rods through the thick mist. Rain is produced in this manner, by the sudden condensation of watery vapor, and dew by the contact of warm moisture-laden atmosphere with the cold ground.

In the hot-bed the same law holds good. The moisture which we have added to the soil is heated and evaporated by the heat above and the heat below, and as the glasses of the sash are several degrees cooler than itself it is forced to deposit in beads, as above stated. 


\section{AIRING THE PLANTS.}

Air should be admitted to the beds only in the forenoon; unless the plants need no watering, in which case they may be aired in the latter part of the day. Many more plants are destroyed by giving too much, than by too little air. The glass should be shaded by mats in the middle of the day, for much loss is caused by a milting of celery roots. This, in fact, is the reason why so many plants run to seed after they are set out, and there are numbers of gardeners who can certify to losses of thousands of dollars from this accident alone. My own loss has amounted to a very large sum. Then 
CELERT.

the plint wilts and is neglected for one or more dars, its sap becomes unhealthr, and in extreme cases so dries out that the stalk becomes pithr, like the bulb of a pithy radish or turnip. If ratered it mar partially rerice, but it can nerer quite recorer from the check it has receired. When transplanted, not haring strength enough for a reaction, it strilses fresh root and shoots up in a desperate effort of nature, and is ruined. The plants taken from the font of the lot-lwed leerhaps escale ruming to seed. lout those from the middle and upler portions fall rictims to the maltreatment they hare receired.

By shading my plants, then, in the middle of the dar I escape the rilting, and still hare the needed amount of moisture. 
If I watered them to avoid the wilting, I should produce a mildew; and the plants would "damp off" at the root. Celery needs but little water, and that in the form of dew. Hot-beds should be watered at the upper part and not at the lower, otherwise the whole crop is endangered. It is easy to know from their aplearance whether the plants reguire watering, tor in such case their leares are of a deeper color, and smaller, than of those which do not need it. My plan is to water twice a week, and shade the beds when the sky is clearest; say from 10 A. M. to 4 P. M.

Gardeners will have observed that in a lot-hed, the plants growing in the shade of a cross-bar of the sash are invariably healthy. They are worth much more 
than the unshaded plants, for they thrive better in the field, and I recommend the application of this principle to the whole sash. I repeat it, it is in vain to hope for a sound saleable crop of celery from damaged plants. There are multitudes of crops of celery that never pay for the expense of their production. Some allow their plants to stand too thickly, and thus get them all tops and no bottoms. Others, from keeping their beds too damp, lose their crops from mildew; and each of a host of others suffer's his especial penalty for the violation of some law of vegetable growth. 
CELERY.

\section{HOEING THE BEDS.}

This must be done only when the leaves are cpuite dry, or the plants will be stricken with rust. Rust I suppose to be caused by the formation of an acid in the sal), which either directly or indirectly starts a process of decomposition in the cells, and ultimately, the destruction of the plant. 
CELERY.

\section{TRANSPLANTING.}

The removal of plants from the hotbed is an operation which reruires great care. It is painful to see the manner in which it is performed in nine cases out of every ten. The delicate rootlets of the young plants are torn from their resting places as if they were of no value whatever, but rather useless appendages to the stem and leaves which might as well as not be dispensed with. The bed should be well watered an hour before the plants are to be removed, for they are thus invigorated, like the man who lunches before starting on a journey, the soil is compacted about the roots, and we are ena- 
bled to pull out only those of good shape and equal size. If the bed be not watered, and the plants are dug instead of being pulled, we not only get them in poorer condition for transplanting, but are apt to get a mixture of sizes, which gives a very variable crop, one which does not admit of one system of treatment being applied to the whole field. If tall and short plants be growing together, it is easy to see that in banking the frame to the required height we should smother the latter, and hence much loss ensues. It is such an eaș matter to have a crop of equal size throughout, by simply using the precantions which I have detailed, that I am prompted to dwell thus earnestly upon this special point.

When the plints are allowed to stand 
too thickly they become worthless when they have gained a height of twelve inches and are planted out, for the sum striking them, their enfeebled constitutions can not resist its heat, and they wilt and die. I have always found that the shorter and more "stocky" my plants are, the stronger they are in the root, and thus the more likely to make vigorous stalks and retain their health.

Celery plants should never be topped before transplanting. Leaves are the lungs of the plant and can be no more dispensed with than can the same organs in the animal. When a plant is poor and spindling, and its roots have been destroyed, it has been a common practice to attempt to counterbalance these losses by topping the plant. 
As I never set out a poor plant I never resort to this make-shift expedient. The comparitive merits of the two plans may readily be tested by planting one row of celery without removing the tops, and another with the nsual treatment. If the superiority of the former practice be not made manifest, the result will differ from what I have observed on my own farm. It has happened to me to raise a poor crop more than once after having taken every precaution, merely because I topped my plants. Experience has taught me these practical results, and experience I have always thought to be the best teacher one can have. It is useless for us to see certain results transpiring before our eyes if we are not led to discover the hidden causes at work to produce 
them. Any fool can see that he is losing his crops year after year. The wise man learns from his losses how to prevent them. 


\section{PREPARING THE TRENCHES.}

Celery can be raised in almost every kind of soil; but a like treatment can not be given to all. Those who fail to raise paying crops must more generally ascribe the result to their careless treatment than to the nature of their soil. It is true a sandy loam, or a spongy muck are best adapted to the celery plant, but with me any kind of soil will answer. If I have a heavy clay loam I am forced to use extra precautions, handling it only when almost dry; whereas with a light sandy loam like the greater part of my farm, I pay but little attention to this matter.

I make my trenches two feet deep and 
one foot wide. Put in well-rotted cattle or hog manure to a deptlı of six inches, and cover it with a like depth of soil taken from the side of the trench. The two layers are then to be thoroughly mixed, and when completed the bottom instead of being left flat is to be raked so as to make a mound, higher in the middle than at the sides. The plants are to be set twelve inches asunder. The trenches made five feet apart. The objection thus mounding the bottom of the trench is that when a heavy shower falls we escape a disaster which often befalls us under the flat system, viz: the smothering of many plants by dirt washed from the banks of the ditch. Some more hardy, or it may be less thickly covered than the rest, may struggle through to the surface, but the 
chances are doubtful. If the plants be set at the center of the mound the dirt washed in merely fills the gutters at either side, and the plants are left unharmed. I have myself lost hundreds of thousands of celery plants, from this smothering, and I doulot not such has been the experience of every other cultivator.

The trenches should be prepared only in clear weather and when the wind is either North or West, for under such circumstances the soil will possess its greatest powel of condensation, and the safety of the crop be more assured. If, however, the ground is plowed when the wind is either South or East this condensing power is materially lessened, for the soil and atmosphere will be more alike in temperature, and as a natural result 
the plants not receiving sufficient moisture from the air must be watered by hand, and will require to be shaded as well. This is all a useless labor and expense, for celery cultivation should be so managed as that no hand watering in the field should ever be recpured. The practice besides causing expense is injurious, for it compacts the surface of the soil and thus destroys its porosity. It makes but little difference as to the heat of the day, if the celery plants are set out soon after the ground is plowed, for the cold orerturned soil will supply abundance of moisture to the plants. The old plan is to prepare the trenches in dry weather, and immediately after a rain-fall to set all hands to work setting the plants. This was formerly my own practice, but sad 
experience has taught me better; for while it is true I cansed my plants to take fresh root, I did enough harm to the soil to almost counterbalanee the profits. By testing the two ways in conjunction I found that the plants set out on a dry day were always healthy and green, while those set after a shower hecame comparatively yellow or brownish in hue. 


\section{HOEING.}

By the usual practice a crop of celery is hoed early in the morning without regard to the state of the soil as regards moisture, and with no reference to the direction of the wind at the time. But what is the penalty of such practice? That which I suffered was the loss of thousands of heads of celery; and such doubtless is the experience of others. Not suspecting the real cause of my failures I tried at great cost every experiment which I could devise, and at last was rewarded by discovering how to ensure a healthy crop. Now I never hoe my celery when either the leaves are wet or the soil is damp, 
I wait for a dry soil and a North or West wind. Thus the plant is supplied with moisture ly the process of conlensation, and is not, as by the usual practice rusted from the disturbance of a moist ground.

Celery is hoed for the first time with two objects in view; to furnish moisture to the crop, and to cover the roots with soil so as to prevent them from being burnt or" "scalded" by the sun. When a plant becomes sun-burnt it rusts, the stallis crack cross wise, the tubes which convey the sap break asunder, and the celery heeomes bitter to the taste. This unfortunate result is clearly the consequence of neglect, and may arise from ignorance or carelessriess.

The first covering should be of not more than three inches of soil over the roots 


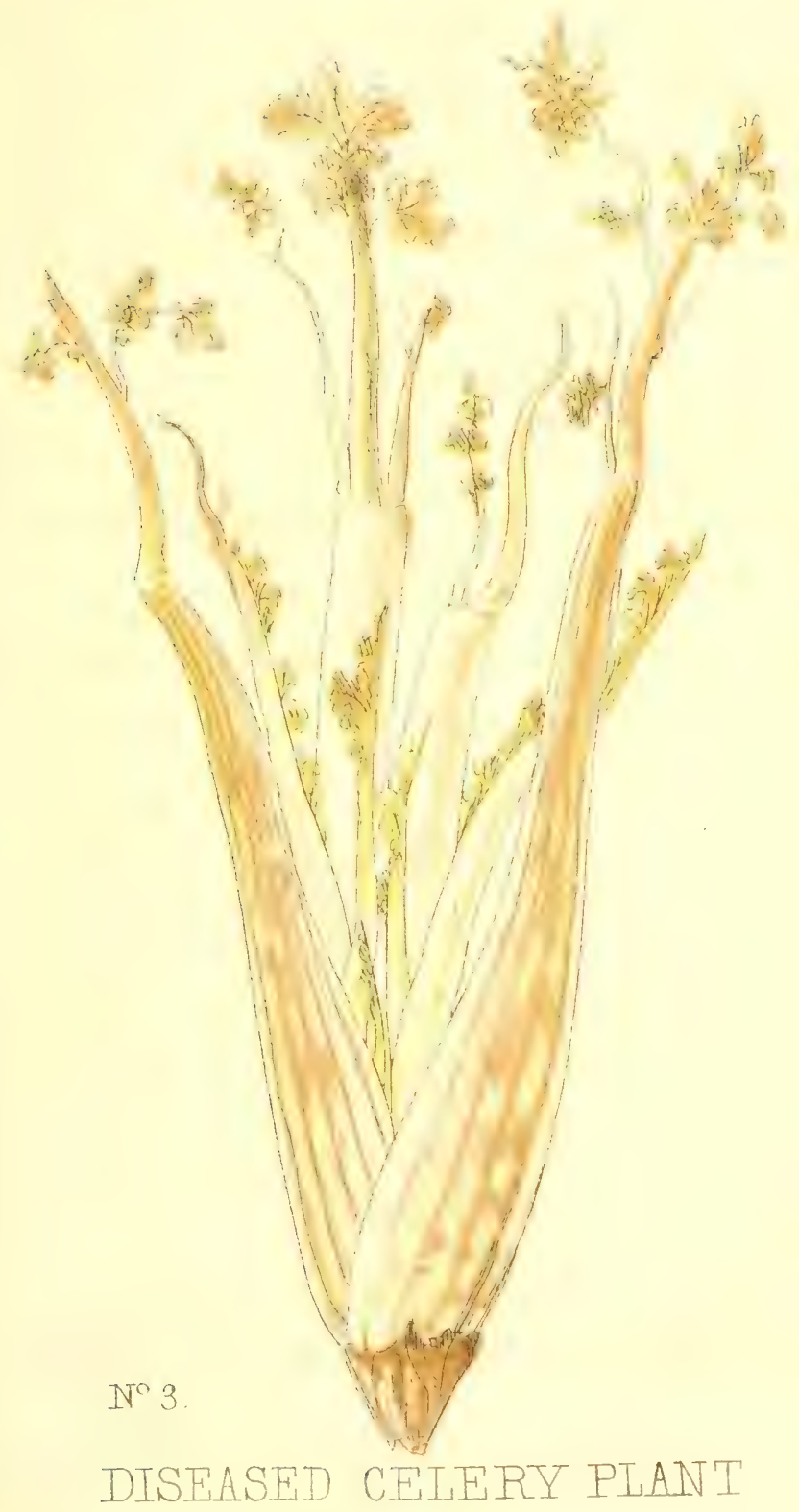



near the surface which put out laterally and serve as feeders to the plant. Those which strike downward supply the plant with moisture, an office which is also performed by the leares at night, for they condense moisture from the atmosphere under farorable conditions. In hoeing we must be cautious not to get dirt into the heart of the plants, else ther will be destroyed as surely as if orertaken by a flood. The heart of the celery plant must be allowed when young to have an abundance of air; many plants are lost from being banked, when they should only be hoed about to kill the weeds, and by stirring the soil furnish moisture. This stirring is of the utmost importance in dry weather, for if the plants are once suffered to wilt there is danger of losing 
the whole crop. Deprived of its regular nutriment by being deprived of moisture in suitahle condition, the stallis of celery become hitter and consequently unhealthy. For this reason there is but little sweet celery to be found in market in Summer, whereas if only proper precantions were used an alomelant supply could be had throughout the entire season. So little indeed have gardeners been able to grow a crop of good quality for Summer use that a popular superstition has arisen that celery is not fit to eat before the first frost. There is not a particle of truth in this assertion, als the Summer guests of the Delavan House cam abundantly testify. It has resulted from the fact, that in the fall months we have no drouth, and the crop once sately past the Summer and 
left to shift for itself a healthy growth is more possible. My plants are taken eare of during the Summer heats, when they need attention most, and not being suffered. to wilt, I am rewarded by a good healthy crop. Celery must be planted in a cool and rather damp place, but it can not withstand any excess of wet, and should nerer be planted where water would stand in a ditch dug to a depth of four feet. 


\section{BANKING.}

This, by the majority of gardeners, is done every few days. They commence to bank up when the plants have only three or four stalks, which is a fatal mistake. By their kindness to the plant they are apt to ruin it, and instead of helping, hinder its growth. So much for not understanding the halits of the plant. Beside, there is no need of all this labor and expense, and hence it is so much sheer waste of capital. My rule is to first aim at getting a large root, and then wait for the plant to get ten stalks, the 
tallest eighteen inches in height. By getting a large root the plant gives me larger stallss, and three or four at a time; whereas, by the old plan of hilling, this hardy growth is prevented, but one stalk is produced at a time, and that a small one. Another reason for deferring the first banking up until the ten long stalks are put forth, is, that the outer ones form around the heart a complete curb, or fence, against the access of soil, which would produce rust and make my crop like that of a thousand other gardener's. Besides, I give the plant as much greater ability to collect moisture for its use as ten stalks are a greater number than three or four, and by so much diminish the liability to turn bitter. I can not urge too strongly this having a number 
of outer stalks to form a curb for the protection of the heart, for it is impossible to prevent rust if dirt once enters, and by my plan the protection is effectual, the onter stallis alone being injured by the soil. These are always to be removed before placing the vegetable upon the dinner-table.

It is currently believed that celery stallis cam be blancherl by hanking after they have become green, and to save all these green stalks, gardener's commence to bank "l) when barely a single stalk has grown, and continue it from time to time at short intervals. By so doing they do nothing to keep the dirt from the heart, leaving its prescrvation to the merest chance.

I aim to get not only large tops and 

abundance of stalks, but a good stout bottom. Those who pursue the old method get a small root, and as a natural consequence, small, feeble stalks. The result which I have at last obtained is, to raise celery which does not rust, is neither pithy nor stringy, and to have an average crop of large hearls, the stalks of which will be as white and clean as a sperm candle. Moreover, I have to expend hut half the labor and money on the crop that I formerly did, and thus make it a very profitable business. Formerly the losses were so great that the crop seldom pair for raising, for if, perchance, I sncceeded in getting a fair crop, I lost it all after it was harvested, from ignorance of the method for preserving it from rotting. I 
would have every gardener study the nature of the plant for himself, and not rely wholly on what I or any other man may say; for with ever so good a hand-book, the cultivator will never get the mastery over the crop so as to handle it with a certainty of profit, unless he study it in eonnexion with his own practical experience. Celery is absolutely one of the easiest regetalules to raine, and the expense of its production should almost nerer exceed one cent per head.

My celery is banked twice only. The first tine is, as I said before, when it has grown to a height of eighteen inches, and I then bank up to the first outside leaf, measuring from the root upward. This leaf is the mark to work by, for if dirt be 
put above this point the celery is apt to decay at the heart, as the loss of full half a crop has often taught to its cultivators. Before banking, the soil between the rows should either be cultivated or hand-hoed, to destroy any weeds that may be growing. This should only be done on a clear day, for otherwise the soil is apt to be too damp, and if any of it comes in contact with the heart will produce decay. This decay commences at the heart leaves, and may be known by their appearing as if dipped in dirty water. From the leaves it extends downward as far as the root, and the loss of the whole plant ensues.

The second banking is done when the heart has grown up even with the outside leaves, and should then be done so that the whole plant is banked to a height of 
two feet. As soon aftel this as the heart has grown up above the outer leaves the celery will be ready for the table; the whole period from the first banking being but four wecks in all. By the old plan it repuines three months to get it three feet high, and for this reason it becomes tough and stringy, sometimes pithy and lusty, and in any case unmarketable. By my plan all lust, pith, stringiness, and toughness is escaped, and the plant is made sweet, crisp, tender, and palatable.

I observe the rule of never hilling colery until alout four weeks hefore it is repuiled for the table, and thus am euabled to hlanch it only as needed for use. If' I need a thousand heads a day through October, I hill that number each day throughout July, and so with other 
months. If an excessive quantity beyond what you need for consumption is blanched, it is liable to spoil. 


\section{DIGGING THE CROP.}

This operation, which should be performed with great care, is too often so managed as to spoil the crop produced with the greatest care. If dug up and suffered to lie exposed to the sun, it wilts and becomes green and pithy. It is also liable to become as rank and strong flavored in the stalk as in the leaves. For this reason, celery after being dug, should be exposed to the light as little as possible, for every hour of unnecessary exposure will reduce its quality in a material degree. 
CELERY.

\section{PREPARING FOR USE.}

When dressed for the talule, care should be taken to have the water perfectly clean, for otherwise the celery will be stained, and can nerel be marle to look as well afterward. After the celery is all washed and bunched, it should be placed in a tight barrel, standing upright and on its roots. Then pour in water to the depth of two inches, which will effectually prevent it from wilting or becoming pithy. In this state it will grow as if still in the ground. The mouth of the barrel should be covered with a cloth thick enough to exclude the light, and the barrel should 
be set in a cool place until the celery is wanted for use. These simple practical directions are but little observed, and herein we have the reason for our seeing so much inferior celery in the public markets. When celery is purchased in market for family use, it should be sent home wrapped in a cloth, or thick paper, and at once put in a cool place, or into cold water, where it should remain until prepared for dinner. To - prepare it, remove all the outside stalks which are not good to eat, and so trim the root that the outer portion, or corky bark, is all removed. Then cut the head in such a way that each stalk shall be attached to a portion of root, for thus each will be furnished with a portion of sap until eaten. Celery should not be put on the table until a few 
CELERY.

minutes before it is to be used. By this means the stalks will retain all that delicate flavor which they receive from the root. 





\section{WINTER CELERY.}





\section{W I N T E C E L E R Y .}

\section{PREPARING TIIE GROUND.}

The land chosen for Fall or Winter celery should if possible be a sandy loam, the location warm but with a cool bottom, and if underdrained so much the better. It will be understood from what has preceded that standing water at the root of celery plants is very injurious, and the question as to the necessity or profit of underdraining, naturally suggests itself. If a man possesses a soil which is underlaid by an open gravelly bottom, it 10 
is probable that his drainage would be naturally perfect, and he would be foolish to lay out capital in underdraining. $\mathrm{My}$ own farm is a light sandy loam and so well drained naturally that I can work it at almost any time. But on wet clays, or heavy clay loams the celery grower is forced to drain, or risk the loss of his crop. Supposing this matter attended to :

The ground should be prepared in the Fall by application of a good coat of cattle or hog manure, plowed or dug under. The land should be laid up in beds about eight feet wide with deep water furrows, that it may be worked earlier in Spring. As soon as the frost is out of the ground and the ground has dried, it should be plowed. A clear day should be chosen, 
and the ground should be laid out in beds eight feet wide, and as long as required. 
CELERY.

\section{SOWING AND HOEING.}

To make the drills, take a board four inches wide and ten feet long (the extra two feet beyond the width of the bed being intended to serve as handles), and two men, at opposite sides of the bed, press the hoard edgewise into the ground to the depth of an inch. The edge of the board is not to be made sharp. The drills are to be made a foot apart. Cover the seed as fast as sown, and when the whole bed is finished give it a light rolling. By so doing the plants will come up alike, as heretofore described. The sprouts will come above ground in about fourteen days. At the first hoeing thin 
the plants so that they will stand at about half an inch apart. The greatest care must be taken not to hoe the crop while the dew is on, for otherwise it will be liable to be stricken with rust. These plants will be ready for setting out in June or early July. They should be hoed only in case of weeds, or if they require water, and then it should only be done when the wind is Northerly or Westerly. The trenches for Winter celery are to be made as for the Summer crop. All celery in the Fall that has not been banked when the first heavy frost appears, should be so treated at once to prevent the frost from destroying it, as the soil is too warm to admit of its being transplanted for winter use.

Care should be used against burying 
celery too soon, else it will strike fresh root and get ready for market before it is wanted. 
CELERY.

79

\section{HOW AND WHERE TO BURY.}

The spot chosen for burying the winter celery must be the coldest on the farm. The North side of a hill, where the soil is perfectly drained, is best. Whenever possible, the cultivator should manage to give to his ground a slope of one foot in four, the better to ensure perfect drainage, and to give an equal Northern exposure to his buried crop. A reference to fig. 4 will explain the appearance of the hill side when so graded. Stretch a garden line from North to South, and dig the trench on the East side of it, two feet deep and one foot wide, throwing the dirt to the West side. This will raise the 
ground a foot higher, and make the whole height from the bottom of the trench three feet. Level the top of the bank, and cut it down perpendicularly. The celery for these trenches should not be dug unless the leaves are perfectly dry. The dirt should be left on the roots as much as possil,le, and the heads are to be laid in a row to dry those leaves that were in the soil; but be careful not to expose them so long that they will commence to wilt. When they have dried enough carry them to the trench, and taking one head at a time, set it against the perpendienlar side of the trench, roots downward, so that the tops of the leaves will he two inches higher than the top of the bank. Take the earth from the Easterly side, and tread the first six inches 
about the roots to set them firmly and encourage the putting forth of new roots. The rest of the way up the stalk the soil should be laid in loosely, and not pressed tight against the celery. If some of the heads are only a foot or eighteen inches high they must be so mixed in and overlapper by the adjoining heads that they will be protected from smothering when the dirt is thrown in. When the trench is all filled with celery, and the lower six inches of soil are packed against the roots, the rest of the dirt may be banked in on the East side to within two inches of the top of the plants, as on the other side. Care must be taken in banking that none of the stallss are bent out of the perpendicular. 
The next trench is to be made not nearer than a foot from the first. The ground is to be leveled, the line stretched, and the trench made as before. The foot-wide space between trenches is needed to keep each row of celery cool. In light soil, such as mine, the second trench must be made only as fast as the celery can be buried, else the bank will cave in. I keep on in this way until I have six trenches of celery, and this bed I make the planting for first use.

Usually, the warmest place is chosen for the celery pits instead of the coldest. Br this sad mistake I have lost thousands of heads, for as soon as a thaw came, the celery would start to grow, and ripening before needed for use, decayed. It is 
CELERY.

easy to make it grow, but hard to check it if once started. Whereas, on the North side of a hill I can control its growth to my liking, and still protect it against freezing and thawing by a proper covering.

There are three errors into which celerygrowers fall. First: digging it up and burying it with the leaves damp, thus causing mildew, decay, and death. Second: knocking the dirt from the roots, and thus leaving them to wilt and become pithy, while the leares are drying; the consequence of which is that when put into trench the stalks become pithy also, before the enfeebled root has a chance to strike fresh rootlets to supply them with sap. Third: burying their Winter celery in damp ground, where there is no under 
84 CELERY.

drain; in which case the roots become saturated with water, regetation ceases, and the roots become black and decay. 
CELERY.

\section{COVERING FOR WINTER.}

The beds being all filled prepare the covering, which may be either rye, or' buckwheat, straw. If the former be used it should be well broken up to prevent it from lying smooth on the bed-a most important point. This covering may be put on the bed which is to be first used, when the ground has frozen three inches; on the second when frozen four inches; on the third when six inches; on the fifth eight inches; and on the last when frozen twelve inches. The first bed is frozen three inches only that it may be ready for market in four weeks from the 
time of burying, and the other depths will ripen a regular succession of beds as wanted one after another.

The covering is put on for two reasons: to keep out the frost; and to keep in what we have already suffered to enter for our own purposes. For this reason, if I had placed my bed in a warm situation, the ground not freezing there as soon as it does on the North side of a hill, the celery would have taken fresh root, and have grown before it could have been checked. My rearler's cannot fail to see the importance of controlling the maturity of celery so as to make it accommodate itself to their convenience, a result which is quite within their power if the frost be allowed to enter in turn to the several depths above mentioned. Since adopting this 
practice I find no trouble in having celery as white and perfect in January as in April; whereas when if all my beds were covered at the same time as the first, that is when the frost had entered but three inches, I should find in Spring that the bed to be last used would have either all run to seed or decayed.

The covering of straw is to be two feet thick, and increased as the weather grows colder. If there should chance to be a fall of snow that must be covered also, to prevent its melting. By so covering it a solid body of ice will be formed, and the protection of your celery be increased. These Winter beds are often covered with a layer of fresh horse manure, which is a practice that can not be too strongly condemned. For, as soon as a thaw sets 
in the strength of the dung, comprising the soluble and most powerful portions, leaches downward, stains the celery, and creates a sort of brown rust which mar's the beauty of the plant, and of course greatly impairs its flaror. In a stroll through the New York markets, a few days since, I saw quantities of celery exposed for sale, which hat modoubtedly been thus injured. This plan of covering with horse-rlung has arisen firem the same fallacious idea as the choice of a Southern aspect for the Winter berk, and is almost as productive of loss to the gardener. Besides which it forces unsuspecting purchasers to eat in their ignorance food flavored in a manner that would and should create absolute nausea, if the truth were known. If the use of this sub- 
stance as a covering were at all necessary I should touch but lightly upon it, but as it most emphatically is not, I protest against it as a disgusting imposition upon the consumer, as well as a serious loss to the producer himself. No man would be so insane as to bury his Winter potatoes or turnips in this substance, under the plea that his cellar was not frost-proof. Why then should he "protect" celery, a vegetable of much more delicate flavor and texture than either, by placing above it, a thick layer of manure, which contains a large amount of substance ready to be washed downward by the first rain! 


\section{DIGGING FOR USE.}

This can be done on any day, no matter how cold the air may be. Care must be taken, however, to place it in a blanket as it is dug to prevent its freezing; for if once frozen it can never be restored to soundness again. This precaution is seldom taken, and the natural consequence is much damaged celery. It does not need that I should again describe the process of washing and preparing celery for the table; but I wish to say a few words in regard to sending it home from 
market, and my city readers will do well to note them.

It is frequently the case that although one may select the very finest of bunches in market, they become spoilt before the purchaser is ready to eat them. This results from either being too much exposed to the light, or from being frozen. Of course it will be understood that these two evils should be guarded against, and the celery, instead of being hung up at the stands of the marketmen, and sent to the purchaser quite mprotected, should be covered with a thick dam!' cloth, both in the market and when heing sent home. How it should be treated after reaching there I have already described.

Thus, in detail, have I described the 
treatment of this most profitable crop, as practiced by myself, after many years of practical experiment. Of the importance of the sugerestions herein contained some idea can be had, when we consider that there are sold in the City of New York alone, several millions of bunches every rear, and its comsumption is constantly on the increase. That it has, in some measure, been regarded as an article of luxury and heyond the reach of the poor, is simply due to the uncertainty which has attended its cultivation. I do not doubt, in fact I know from personal experience, that sometimes, with even the highest market prices, celery culture has not paid its bare expenses. This is an entirely umnecessiny state of things, and I confidently assert that if gardeners will 
CELERY.

fairly follow the directions laid down in this unpretentious little treatise, they will find celery fully as certain a crop as turnips or potatoes, and more profitable than either. 



\section{OTHER HAND-BOOKS.}





\section{OTHER HAND-BOOKS.}

I propose to publish, at intervals, as my onerous engagements may permit, HandBooks on other culinary Vegetables, each of which will contain facts of value, the result of my own experience. Those which I now have in view are treatises on :

Potatoes.

How to raise a healthy Potato crop without. rot.-The three different kinds of rot, attacking the root and stalk shall be described, and my mode of avoiding them 13 
be given. I will describe the mode of keeping Potatoes through the Winter without sprouting, and without impairing their flaror. Also, where and how to plant them; how much and what manure they need; whether and when to use, cut or whole seed; how many eyes should be left on a set; and other particulars.

\section{CORN.}

How to raise a large crop of Sweet, Yellow, or other kind of Corn every year, without having it stricken with lust or any other disease; how and when to plow; to plant so as to make the plants come up evenly; to manure; to hoe for the first time; to cultivate; to hill; to supply the crop with moisture in severe dlouths without hand watering; to cure so as to 
best ensure ripening; and to keep the stalks throughout Winter.

\section{Cauliflowers.}

How to raise Cauliflower's so that they will all head; how to prevent their running to seed; to preserve the root against maggots; to prevent clump-foot ; and how to keep them through the Winter without rotting.

\section{Cabbage.}

How to raise any kind of Cabbage, in hot-beds or the field, without having them "damp-off" or become clump-footed; how to prevent injury from maggots, lice, or other insects; to prepare the soil; manure; cultivate, harvest, and preserve the crop. 


\section{Turnips.}

How to raise Early Tumips, perfectly clear, and free from maggots. The soil, culture, and treatment to give them, and how to best keep them over Winter.

In like manner I propose to treat the ('arrot, Beet, Parsnip, Radish, Onion, Cucumber, Melon, Squash, and the other Vegetables in turn. 



(2)
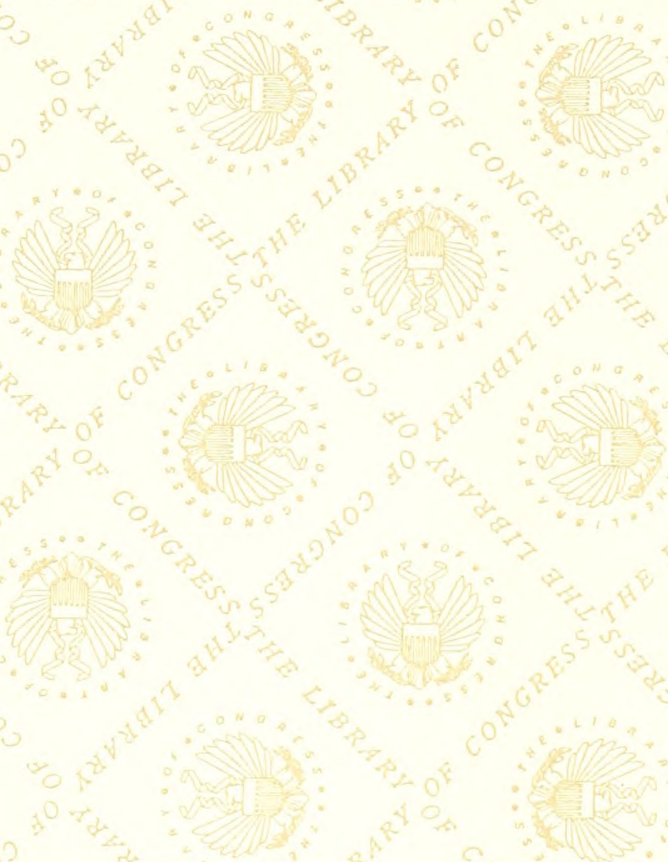

$n^{0} \%$
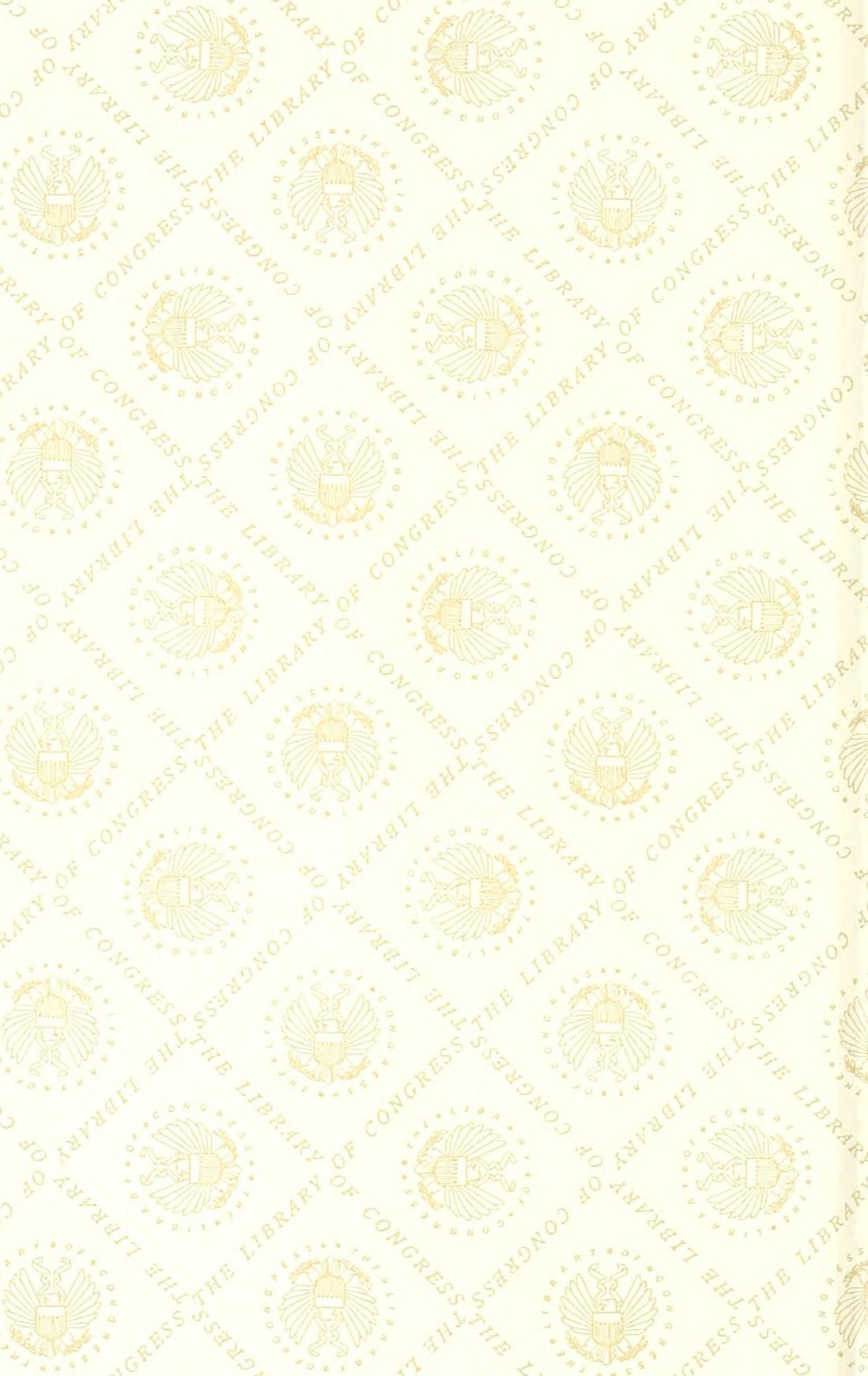
307
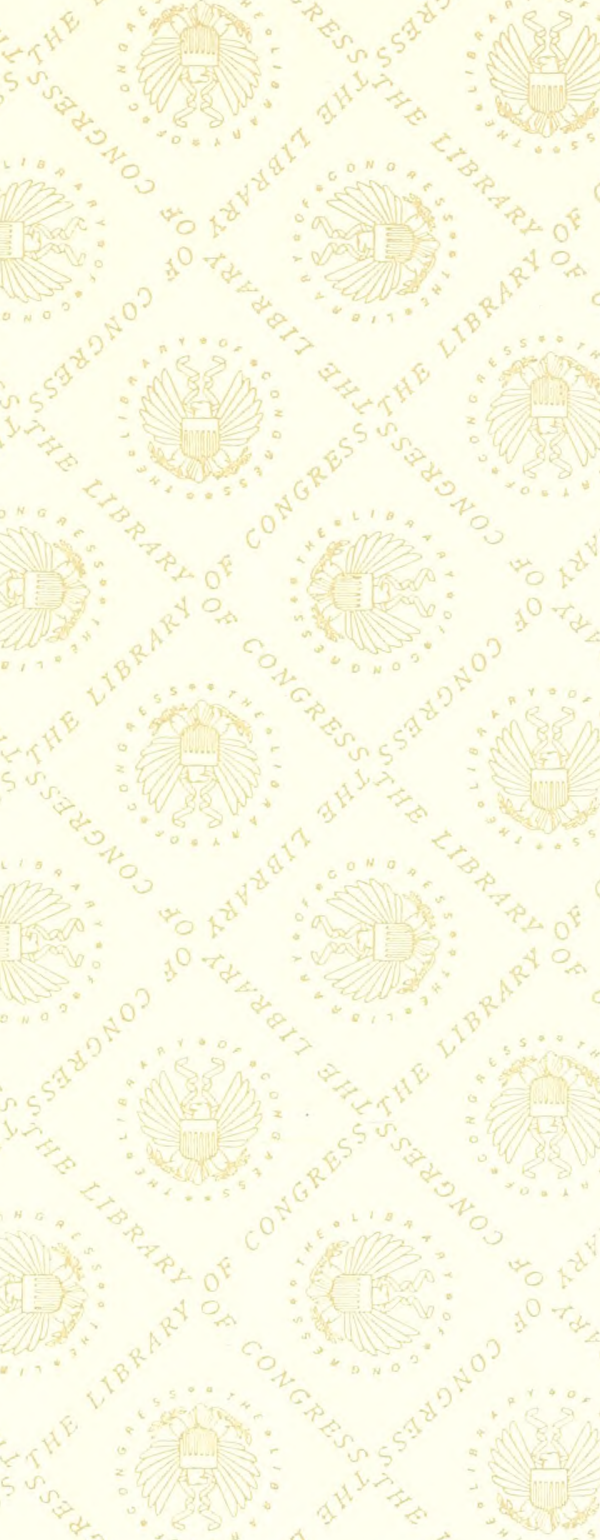

DORBS BROS.

LITRARY BINDING

ST. AUGUSTINE 6

FLA. 
LIBRARY OF CONGRESS

|||||||||||||||||||||||||||||||||||||||||

|||||||||||||||||||||||||||||||||||||||||||||||||||||||||||||||

0000916?146 